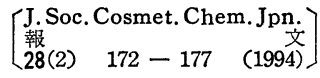

\title{
活性酸素の培養ヒト皮膚線維芽細胞におけるコラーゲン代謝に及ぼす影響
}

\author{
田中 浩, 岡田富雄 \\ 日本メナード化粧品株式会社 生化学研究所
}

\section{Effect of Reactive Oxygen Species on Collagen Metabolism in Cultured Human Dermal fibroblasts}

\author{
Hiroshi Tanaka and Tomio Okada \\ Biochemical Research Institute, NIPPON MENARD COSMETIC Co., LTD.
}

\begin{abstract}
The excessive loss of collagen is well known in photoaging skin. Collagen is synthesized by dermal fibroblasts and enzymatically digested by collagenase. Therefore, the quantitative alteration of collagen depends on the balance of synthesis and digestion. Skin is always exposed to oxygen stress and is suggested to be frequently generated the reactive oxygen species (ROS). We investigated the effect of ROS induced by xanthine-xanthine oxidase system on collagen production and collagenase activity in cultured human dermal fibroblasts. Collagen synthesis which was assessed by measuring ${ }^{3} \mathrm{H}$-proline incorporation into extracellular collagen, was decreased by ROS exposure. Collagenase activity was measured by using DNP-peptide as a synthetic substrate of collagen and increased by ROS exposure. These changes supported the biological alteration of collagen observed in photoaging skin. Extracts of Chouji and Gennosyouko which have superoxide-scavenging activity, prevented the ROS-induced changes significantly. These results suggest that ROS may be one of the factors which cause the decrease of collagen observed in photoaging skin.
\end{abstract}

\section{1. 緒言}

日光露出部である, いわゆる光加齢皮䖉では組 織学的にコラーゲン線維の著明な減少が知られて いる11。真皮のコラーゲン線維は線維芽細胞によ り生成され, 線維芽細胞が産生するコラゲナーゼ の作用により酵素分解を受ける。これら生成と分 解のバランスによりコラーゲン線維は量的に維持 されていると考えられる。したがって，光加齢皮 膚に持けるコラーゲン線維減少の原因にはその生 成の減少と分解の促進のいずれか, あるいは両方

† 5503 岐阜県大垣市浅草 4-66 ; 4-66 Asakusa, Ogaki, Gifu, 503 Japan
の作用が考えられる。

一方，皮覤は絶えず酸素ストレスに曝されてお

り, 活性酸素の発生し易い臓器といえる。また, 露光部では紫外線によって活性酸素が発生し, 過 酸化脂質レベルが高くなることが知られて括り2), 3)，近年，光加齢皮膚にみられるコラーゲン線維 の著明な減少の原因として活性酸素の影響が考え られている。

そこで今回，培養ヒト皮膚線維芽細胞を用い， コラーゲン生成およびュラゲナーゼ活性に及ぼす 活性酸素の影響について検討した。また，合わせ て活性酸素消去作用を有する生薬の効果について も検討した。 
2. 実

験

\section{1 細胞培養}

実験には正常ヒト皮膚線維芽細胞（理化学研究 所・細胞開発銀行 NB1RGB) を10\% FCS を 含导 Eagle's minimum essential medium (MEM) にて $5 \% \mathrm{CO}_{2}, 37^{\circ} \mathrm{C}$ 条件下で培養し, 継代数 6 ～ 8 の細胞を用いた。

\section{2 活性酸素および消去郕}

活性酸素は xanthine-xanthine oxidase 系 により発生させた。すなわち, 培養液中に最終濃 度 xanthine $100 \mu \mathrm{g} / \mathrm{ml}$, xanthine oxidase (XOD) 10 または $100 \mu \mathrm{U} / \mathrm{ml}$ になるようにそれ ぞれ添加して発生させた。また，活性酸素による 培養ヒト皮膚線維芽細胞に打けるコラーゲン生成 およびュラゲナーゼ活性の変化に及ぼす活性酸素 消去剂の影響を検討する目的でラジカルスカベン ジャーである superoxide dismutase (SOD, $100 \mathrm{U} / \mathrm{ml})$, catalase $(50 \mathrm{U} / \mathrm{ml})$, 抗酸化剂であ る $\alpha$-tocopherol $(20 \mu \mathrm{g} / \mathrm{ml})$ および superoxide anion $\left(\mathrm{O}_{2}^{-}\right)$消去作用を有することが報告されて いるチョウジ，ゲンノショウコ，シャクヤク抽出 物 $(100 \mu \mathrm{g} / \mathrm{ml})$ を用いた文。なお，今回の実験に 用いた xanthine，XOD 和よび各消去剂は細胞 数に影響を及法さない濃度で用いた。

\section{3 コラーゲン生成量の測定}

定常期のコンフルェントな状態のヒト皮膚線維 芽細胞に和けるコラーゲン生成量の測定は Webster らの方法 ${ }^{5)}$ に従い, 生成されるコラーゲン 中への ${ }^{3} \mathrm{H}$-proline の取り込みを指標として行っ た。すなわち，ヒト皮膚線維芽細胞を 96 well プ レートに各 well あたり $2.5 \times 10^{4}$ 個ずつ播種し，

$10 \% \mathrm{FCS}$ を含む MEM $0.2 \mathrm{ml}$ にて 4 日間培養 した。この間に細胞はコンフルェントな状態とな った。次に試料を溶解した FCS 無添加の MEM $(50 \mu \mathrm{g} / \mathrm{ml} \mathrm{L}$-ascorbic acid, $50 \mu \mathrm{g} / \mathrm{ml} \beta$-aminopropionitrile, $92.5 \mathrm{KBq} / \mathrm{ml}{ }^{3} \mathrm{H}$-proline 含 有） $0.2 \mathrm{ml}$ に交換し，24時間培養した。その後, $1 \mathrm{mg} / \mathrm{ml}$ ペプシン溶液を各 well ${ }^{3} \mathrm{H}$-proline ラベルされたコラーゲンを抽出し, 酸性および中性下に打いて塩析により精製した。
最終的な沈澱物を $0.5 \mathrm{M}$ 酰酸に溶解後, 液体シン チレーションカウンター(Beckman LS5801)に てコラーゲンに取り込まれた ${ }^{3} \mathrm{H}$ 活性を測定し た。

\section{4 コラゲナーゼ活性の測定}

定常期のコンフルェントな状態のヒト皮膚線維 芽細胞に和けるコラゲナーゼ活性の測定は合成基 質法6)により行った。すなわち，ヒト皮膚線維芽 細胞を $60 \mathrm{~mm}$ シャーレに $1 \times 10^{5}$ 個ずつ播種し， 10\% FCS を含む MEM $4 \mathrm{ml}$ にて 8 日間培養し た。な拉，培養液は 4 日毎に交換し，この間に細 胞はコンフルェントな状態となった。次に培養液 を除去し，試料を溶解した FCS 無添加の MEM $4 \mathrm{ml}$ にて 24 時間培養した。その後, 細胞を剥離 し，超音波破砕したものを酵素試料液とした。

コラゲナーゼ合成基質 $\left(5 \times 10^{-4} \mathrm{M} \quad \mathrm{DNP}\right.$ Pro-GIn-Gly-Ile-Ala-Gly - GIn - D Arg, $0.15 \mathrm{M} \mathrm{NaCl}, 5 \mathrm{mM} \mathrm{CaCl} 2$ を含む $50 \mathrm{mM}$ トリス緩衝液（pH 7.5）に溶解） $0.1 \mathrm{ml}$ に酵素 試料液 $0.1 \mathrm{ml}$ を加光, 遮光下, $37^{\circ} \mathrm{C}$ で 1 時間反 応させた。 $1 \mathrm{~N} \mathrm{HCl} 0.5 \mathrm{ml}$ を加兄反応を停止後, ethyl acetate-n-butanol (3:1) $1 \mathrm{ml}$ とともに 激しく振盜し, 分解産物を有機溶媒層に抽出し た。遠心後, 有機溶媒層の吸光度 $(365 \mathrm{~nm})$ を測 定した。

\section{5 タンパク生成量の測定}

活性酸素による細胞障害性を知る目的で, 培養 上清中に生成されるタンパク量を測定した。培養 上清中のタンパク量は Bradford の色素結合法7) (BIO-RAD Protein Assay Kit) を用いて定 量した。

\section{3. 結果}

\section{1 活性酸素のコラーゲン生成に及ばす影響} 活性酸素の培養七ト皮膚線維芽細胞に打けるコ ラーゲン生成に及ぼす影響を検討した結果を Fig.-1 に示した。

$100 \mu \mathrm{g} / \mathrm{ml}$ xanthine と 10 および $100 \mu \mathrm{U} / \mathrm{ml}$ XOD により発生した活性酸素はコラーダン生成 量を有意に抑制した。

一方, $100 \mu \mathrm{g} / \mathrm{ml}$ xanthine おちよび $100 \mu \mathrm{U} / \mathrm{ml}$ 


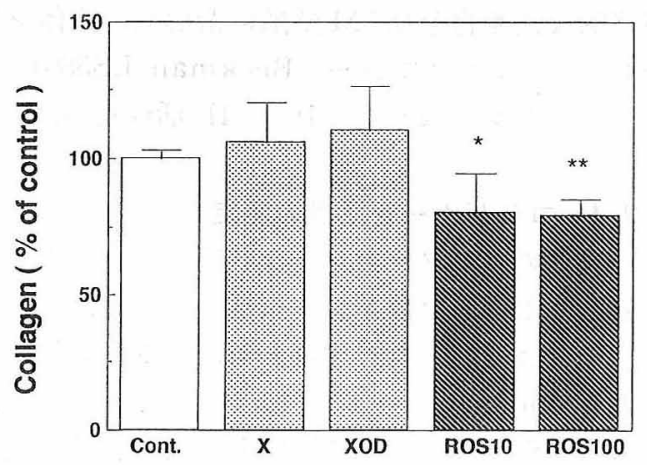

Fig.-1 Effect of reactive oxygen species on collagen production in cultured human dermal fibroblasts.

$\mathrm{X}: 100 \mu \mathrm{g} / \mathrm{ml}$ xanthine

$\mathrm{XOD}: 100 \mu \mathrm{U} / \mathrm{ml}$ xanthine oxidase

ROS10 : 100 $\mu \mathrm{g} / \mathrm{ml}$ xanthine $+10 \mu \mathrm{U} / \mathrm{ml}$ xanthine oxidase

ROS100: $100 \mu \mathrm{g} / \mathrm{ml}$ xanthine $+100 \mu \mathrm{U} /$ $\mathrm{ml}$ xanthine oxidase

Each value represents the mean \pm S.D. $(n=5)$.

** $: \mathrm{p}<0.01, *: \mathrm{p}<0.05$, significantly different from control (Student's $t$-test).

XOD はそれぞれ単独ではコラーゲン生成に影響 を及ぼさなかった。

また，活性酸素のタンパク生成に及ぼす影響を 検討した結果を Fig.-2 に示した。

トータルのタンパク生成量は活性酸素により減 少することはなく，100 $\mathrm{g} / \mathrm{ml}$ xanthine と $100 \mu$ $\mathrm{U} / \mathrm{ml} \mathrm{XOD}$ により発生した活性酸素では有意な 増加がみられた。

\section{2 活性酸素のコラゲナーゼ活性に及ばす影響}

活性酸素の培養七ト皮膚線維芽細胞に和けるコ ラゲナーゼ活性に及ぼす影響を検討した結果を

Fig.-3に示した。

$100 \mu \mathrm{g} / \mathrm{ml}$ xanthine と $100 \mu \mathrm{U} / \mathrm{ml}$ XOD $に$ より発生した活性酸素はコラゲナーゼ活性を有意 に促進した。

一方, $100 \mu \mathrm{g} / \mathrm{ml}$ xanthine 物よび $100 \mu \mathrm{U} / \mathrm{ml}$ XOD はそれぞれ単独ではコラゲナーゼ活性に影 響を及ぼさなかった。

\section{3 活性酸素によるコラーゲン生成の変化に 対する活性酸素消去剤の影響}

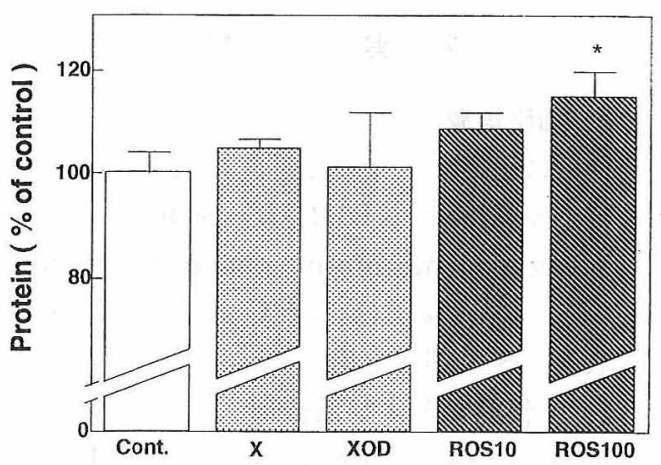

Fig.-2 Effect of reactive oxygen species on protein production in cultured human dermal fibroblasts.

$\mathrm{X}: 100 \mu \mathrm{g} / \mathrm{ml}$ xanthine

XOD : $100 \mu \mathrm{U} / \mathrm{ml}$ xanthine oxidase

ROS10 $: 100 \mu \mathrm{g} / \mathrm{ml}$ xanthine $+10 \mu \mathrm{U} / \mathrm{ml}$ xanthine oxidase

ROS100:100 $\mu \mathrm{g} / \mathrm{ml}$ xanthine $+100 \mu \mathrm{U} /$ $\mathrm{ml}$ xanthine oxidase

Each value represents the mean $\pm \mathrm{S}$. D. $(n=3)$.

$*: \mathbf{p}<0.05, \quad$ significantly different from control (Student's $t$-test).

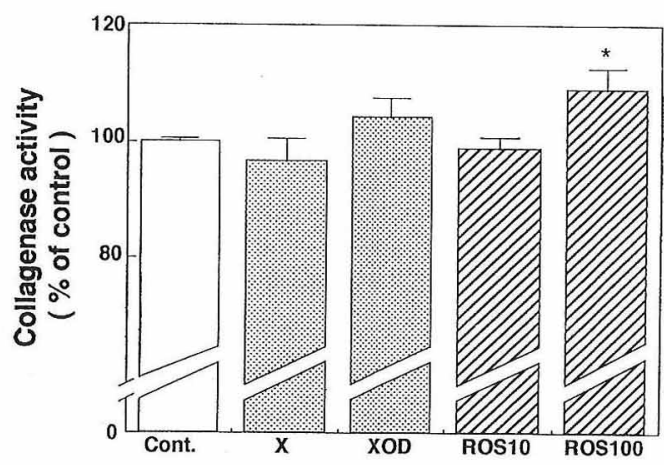

Fig.-3 Effect of reactive oxygen species on collagenase activity in cultured human dermal fibroblasts.

$\mathrm{X}: 100 \mu \mathrm{g} / \mathrm{ml}$ xanthine

XOD $: 100 \mu \mathrm{U} / \mathrm{ml}$ xanthine oxidase ROS10:100 $\mu \mathrm{g} / \mathrm{ml}$ xanthine $+10 \mu \mathrm{U} / \mathrm{ml}$ xanthine oxidase

ROS100 $: 100 \mu \mathrm{g} / \mathrm{ml}$ xanthine $+100 \mu \mathrm{U} /$ $\mathrm{m} 1$ xanthine oxidase

Each value represents the mean $\pm \mathrm{S}$. D. $(n=3)$.

* : $\mathrm{p}<0.05, \quad$ significantly different from control (Student's $t$-test).

ラジカルスカベンジャーである SOD と cata- 
lase 特よび抗酸化剂である $\alpha$-tocopheror の活 性酸素によるコラーゲン生成の減少に及ぼす影響 を検討した結果を Fig.-4 に示した。

catalase および $\alpha$-tocopherol は活性酸素に よるコラーゲン生成の減少を抑制し，その場合の コラーゲン生成量はコントロールとほとんぞ差が なかった。一方，SOD は活性酸素によるコラー ゲン生成の変化に影響を及ぼさなかった。

また， $\mathrm{O}_{2}$ - 消去作用を有することが報告されて いる4) チョウジ，ゲンノショウコ拈よびシャクヤ ク抽出物の活性酸素によるコラーゲン生成の減少 に及ぼす影響について検討した結果を Fig.-5に 示した。

$$
\text { チョウジ，ゲンノショウコ㧤よびシャクヤク抽 }
$$
出物は活性酸素によるコラーゲン生成の減少を有 意に抑制した。

3.4 活性酸素によるコラゲナーゼ活性の 変 化 に対する活性酸素消去刘の影響

活性酸素によるコラゲナーゼ活性の上昇に及ぼ す SOD, catalase 特よび $\alpha$-tocopherol の影 響を検討した結果を Fig.-6 に示した。

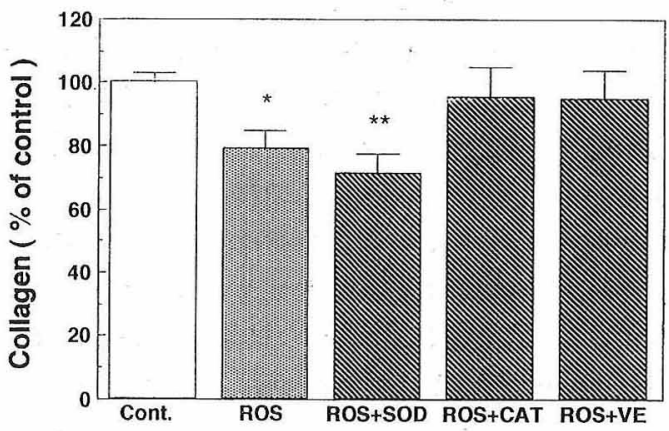

Fig.-4 Effect of scavengers on ROS-induced change of collagen production in cultured human dermal fibroblasts.

ROS : $100 \mu \mathrm{g} / \mathrm{ml}$ xanthine $+100 \mu \mathrm{U} / \mathrm{ml}$ xanthine oxidase

SOD : $100 \mathrm{U} / \mathrm{ml}$ superoxide dismutase

CAT $: 50 \mathrm{U} / \mathrm{ml}$ catalase

VE $: 20 \mu \mathrm{g} / \mathrm{ml} \alpha$-tocopherol

Each value represents the mean $\pm S$. D. $(n=5)$.

**: $\mathrm{p}<0.01, *: \mathrm{p}<0.05$, significantly different from control (Student's $t$-test). catalase 预よび $\alpha$-tocopherol は活性酸素に よるコラゲナーゼ活性の上昇を抑制したが，SOD

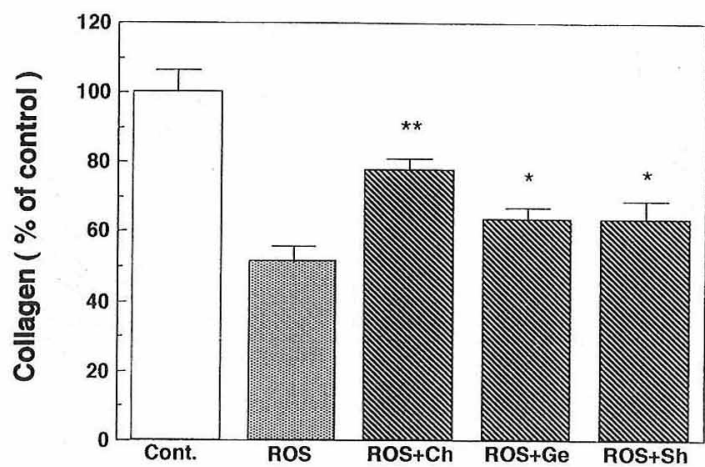

Fig.-5 Efect of crude drug extracts on ROSinduced change of collagen production in cultured human dermal fibroblasts.

ROS : $100 \mu \mathrm{g} / \mathrm{ml}$ xanthine $+100 \mu \mathrm{U} / \mathrm{ml}$ xanthine oxidase

Ch : Chouji

Ge : Gennosyouko

Sh : Shakuyaku, 100 $\mu \mathrm{g} / \mathrm{ml}$

Each value represents the mean $\pm \mathrm{S}$. D. $(n=5)$.

** $: \mathrm{p}<0.01, *: \mathrm{p}<0.05$, significantly different from ROS (Student's $t$-test).

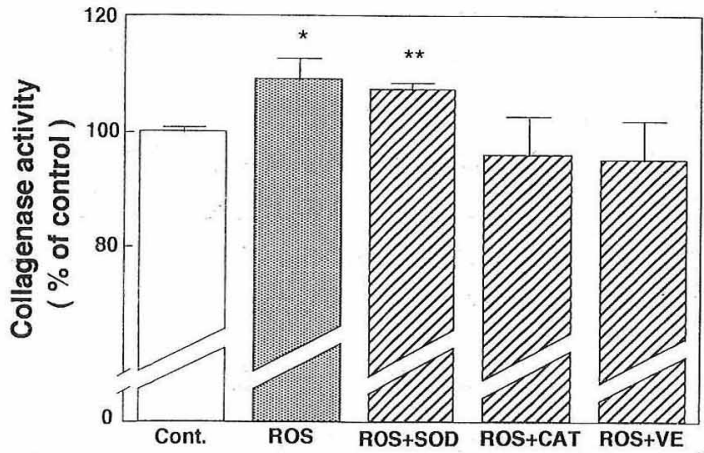

Fig.-6 Effect of scavengers on ROS-induced change of collagenase activity in cultured human dermal fibroblasts.

ROS $: 100 \mu \mathrm{g} / \mathrm{ml}$ xanthine $+100 \mu \mathrm{U} / \mathrm{ml}$ xanthine oxidase

SOD : $100 \mathrm{U} / \mathrm{ml}$ superoxide dismutase CAT $: 50 \mathrm{U} / \mathrm{ml}$ catalase

VE : $20 \mu \mathrm{g} / \mathrm{ml} \alpha$-tocopherol

Each value represents the mean $\pm S$. D. $(n=3)$

$* *: \mathrm{p}<0.01, *: \mathrm{p}<0.05$, significantly different from control(Student's $t$-test). 


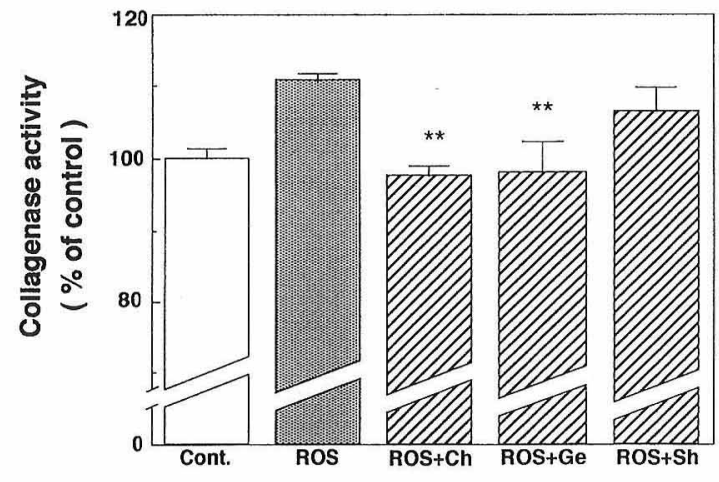

Fig.-7 Effect of crude drug extracts on ROSinduced change of collagenase activity in cultured human dermal fibroblasts. ROS : $100 \mu \mathrm{g} / \mathrm{ml}$ xanthine $+100 \mu \mathrm{U} / \mathrm{ml}$ xanthine oxidase

$\mathrm{Ch}:$ Chouji

Ge : Gennosyouko

Sh : Shakuyaku, $100 \mu \mathrm{g} / \mathrm{ml}$

Each value represents the mean $\pm S$. D. $(n=3)$.

** : $\mathbf{p}<0.01$, significantly different from ROS (Student's $t$-test).

は影響を及ぼさなかった。

また，活性酸素によるコラーゲナーゼ活性の上 昇に及ぼすチョウジ，ゲンノショウコ叔よびシャ クヤク抽出物の影響について検討した結果を Fig.-7 そ示した。

チョウジ特よびゲンノショウコ抽出物は活性酸 素によるコラゲナーゼ活性の上昇を有意に抑制し たが、シャクャク抽出物については抑制傾向はみ られたが有意な差ではなかった。

\section{4. 考察}

日光露光部にみられる光加齢皮盧に和いては, コラーゲン線維が著明に減少していることが知ら れている ${ }^{1 。}$ 。の原因として我々は真皮に捈いて 発生する活性酸素の線維芽細胞に対する傷害性を 考古, 活性酸素の真皮コラーダン代謝に及ぼす影 響について検討した。その結果, xanthine-XOD 系により発生した活性酸素は培養ヒト皮膚線維芽 細胞に持けるコラーゲン生成を抑制し、コラゲナ 一ゼ活性を促進した。これらの結果から, 真皮に 拈いて発生した活性酸素は線維芽細胞に作用し,
コラーゲン生成を減少させ，さらに分解を促進し て, 結果的にコラーゲン量が減少するのではない かと考兄られた。この変化は光加齢皮膚の真皮細 胞外マトリックスにみられる変化 ${ }^{1)}$ と一致するも のであった。但し，今回の合成基質を用いたコラ ゲナーゼ活性測定法は，その基質特異性に問題が あり ${ }^{8)}$, コラーゲン分解に関わるコラゲナーゼ, ゼラチナーゼ等の線維芽細胞が産生するマトリッ クスメタロプロテアーゼの総活性を測定している 括それがある。したがって、コラーゲン分解に関 しては今後, 他の方法と合わせてコラゲナーゼお よびゼラチナーゼ等個々の活性の変化を調べて行 く必要があると考える。

また，活性酸素によりタンパク生成量の有意な 増加がみられたが，培養系に拉いて紫外線によっ てストレスタンパクが生成されることが知られて いることから9)，活性酸素の刺激に応答して線維 芽細胞がストレスタンパク様の物質を生成した可 能性が考えられた。

今回みられたコラーゲン生成およびュラゲナー ゼ活性の変化が活性酸素の影響によるものであれ ば，活性酸素消去物質はこれらの変化を抑制する と考光られる。そこで活性酸素消去物質としてラ ジカルスカベンジャーである SOD, catalase, 抗 酸化剂である $\alpha$-tocopherol 拈よび $\mathrm{O}_{2}$ - 消去作 用を有することが報告されている生薬抽出物4)の らちその活性が強いチョウジおよびゲンノショウ コと中程度のシャクヤクを選び, 活性酸素による コラーゲン生成拉よびュラゲナーゼ活性の変化に 対する影響を検討した。㕣の結果，catalaseおよ び $\alpha$-tocopherol は活性酸素によるコラーゲン生 成叔よびュラゲナーゼ活性の変化をほぼ完全に抑 制したが，SOD はこれらの変化に影響を及ぼさ なかった。Xanthine-XOD 系では, $\mathrm{O}_{2}{ }^{-}$之過酸 化水素が発生し， $\mathrm{O}_{2}$ - は SOD により過酸化水素 に変換される。過酸化水素は catalase, glutathione peroxidase 等の作用により水と酸素に分 解され，無毒化されるが，一方では非常に傷害性 の強い hydroxy radical $(・ \mathrm{OH})$ に変化するこ とが知られている10)。今回の結果では, SODが活 性酸素による変化に影響を及ぼさなかった。これ 
は，今回用いた培養系では生体系とは異なり過酸 化水素を無毒化する catalase や glutathione peroxidase 等が不十分であったために SOD が $\mathrm{O}_{2}{ }^{-}$から過酸化水素への変換を促進しても, それ を充分に無毒化できず，傷害性の強い・OH に変 化したためではないかと考える。また活性酸素消 去物質の影響を検討した結果から，今回みられた コラーゲン生成およびュラゲナーゼ活性の変化は 過酸化水素あるいはそれから発生した・OHによ り引き起こされたのではないかと考えられた。

チョウジ，ゲンノショウコ拉よびシャクヤク抽 出物は活性酸素によるコラーゲン生成の減少を有 意に抑制した。活性酸素によるコラゲナーゼ活性 の変化に対してはチョウジ执よびゲンノショウコ は有意な抑制効果を示したが、シャクヤクは有意 な効果を示さなかった。伊藤らは各種生薬抽出物 の $\mathrm{O}_{2}-$ 消去作用について検討し，チョウジおよ びゲンノショウコ抽出物はとの作用が強いこと, またシャクヤク抽出物は中程度であることを報告 して物り ${ }^{4)}$, 今回のコラーゲナーゼ活性の結果と 一致した。また, 生薬抽出物の $\mathrm{O}_{2}$-消去の反応機 構は SOD による $\mathrm{O}_{2}^{-}$の不均化反応とは異なる ものであると考えられた。

今回の結果は, あくまで in vitro の実験から の推論であり，必ずしもin vivo を反映するもの ではないかも知れない。しかし，少なくとも今回 の結果は光加齢皮膚にみられるコラーゲンの変化 と一致するものであり，皮膚の光加龄変化の原因 に活性酸素の関与を裏付けるものであると考え
る。今後, in vivoへの移行を検討して行きたい。

\section{5. 総 括}

今回の結果から，真皮に拈いて発生する活性酸 素が光加龄皮膚にみられるコラーゲン線維の著明 な減少の原因のひとつである可能性が示唆され た。また，チョウジ拉よびゲンノショウコ抽出物 が光加齢皮膚にみられるコラーゲン線維の減少を 抑制する可能性が示唆され，化粧品への応用が期 待される。

\section{参考文 献}

1) L.M. Kligman and A.M. Kligman, Photodermatol., 3, 215 (1986)

2) A.L. Noris, J. Invest. Dermatol., 39, 445 (1962)

3) H. Meffert et al., Experimentia, 32, 1397 (1976)

4) 伊藤三明ら, 香粧会誌, 14, 196 (1990)

5) D.F. Webster and W. Harvey, Anal. Biochem., 96, 220 (1979)

6) Y. Masui et a1., Biochem. Med., 17, 215 (1980)

7) M.M. Bradford, Anal. Biochem., 72, 248 (1976)

8）鶴 大典, 船津 勝, “蛋白質分解酵素 I” p. 139 (1993) 学会出版センター

9) T. Muramatsu et al., J. Invest. Dermatol., 98, 786 (1992)

10）大柳善彦, “SOD と活性酸素調節剤 その薬理作 用之臨床応用” p. 3 (1989) 日本医学館

(1994年 2 月 18 日受理) 